し弱の吸収がそれぞれ 3〜4個ずつ存在する。ホルマール類，ア セタール類化合物了およびホルムアルデヒド, ホルムアルデヒドー $d_{2}$ ポリマー8のスペクトルの帰属から類推して，この領域の吸収 を種々の官能基に含まれるメチレン基の縦ゆれおよびひねり振動 と帰属する。

領域 D $\left[1230 \pm 9 \mathrm{~cm}^{-1}\right] ： 3$ 種のオルト脂肪酸メチル（闵 2 ， $3,4)$ はこの領域に強度強ないし中の吸収をもつが, オルトギ酸 エチル,オルトギ酸 $n$ ーブチルはこの領域に強い吸収をもたない。 したがってオルト脂肪酸メチルのこの領域の吸収は $-\mathrm{c}=\frac{-\mathrm{OCH}_{3}}{-\mathrm{OCH}_{3}}$ 骨格の特性振動と考えられる。いかなる種類の振動であるかをき めることは困難であるが， $\mathrm{CH}_{3} \mathrm{O}$ 基のメチル横ゆれ振動と $\mathrm{CO}$ 伸縮振動とが結合したものと考えるのがもっとも妥当である。才 ルトプロピオン酸エチルの強度中の吸収は酸のアルキル基中のメ チレン基の縦ゆれまたはひねり振動であろう。

領域 E [1200 950 $\left.\mathrm{cm}^{-1}\right]$ : この領域には CO 伸縮振動, メ チルおよびメチレン横ゆれ振動があらわれる4)67)。エーテル類， ホルマール類, アセタール類化合物の場合と同様にこの領域のス ペクトルは各化合物ともきわめて複雑で，単なるスペクトルの対 比のみからいちいち帰属を行なうことはきわめてさずかしい。し かし各スペクトルをさきに述べたグループ I， I， I に分類してみ るとつぎのような帰属が可能となる。

グループ I - $\frac{\mathrm{C}}{\mathrm{OCH}_{3}} \underset{\mathrm{OCH}_{3}}{\mathrm{OCH}_{3}}$ 骨格をもったもの（図 2〜4): 1170 〜1100 および 1070〜 $1035 \mathrm{~cm}^{-1}$ にそれぞれ 1 個ないし 3 個の非 常に強い吸収をもつ。オルトギ酸メチル，オルト酢酸メチルはメ チレン基をもっていないからこれらの吸収はメチレン基によるも のではない。したがって CO 伸縮振動とメチル横ゆれ 振動とが 結合したものと考えるのがもっとも妥当である。

グループ II H-C $\leq \begin{aligned} & \mathrm{O}-\mathrm{CH}_{2-} \\ & \mathrm{O}-\mathrm{CH}_{2-}^{-}\end{aligned}$ $\sim 1010 \mathrm{~cm}^{-1}$ の範囲内に 1 個ないし 2 個の非常に強い吸収をむ つ。この骨格にはメチル基を含まないからこれらの吸収はメチル 基によるものではない。したがって CO 伸縮振動とメチレン横

8) H. Novak, E, Whalley, Trans. Faraday Soc. 55, 1484 (1959).
やれ振動とが結合したものと考えるのがもっとも妥当である。こ のグループのスペクトルのもう一つの特脣は $1181 \sim 1010 \mathrm{~cm}^{-1}$

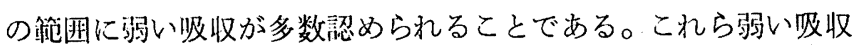
の帰属を行なうことは現在の段階では不可能である。

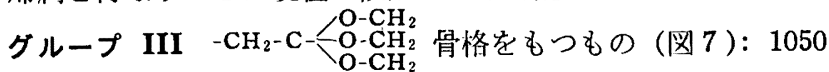
$\mathrm{cm}^{-1}$ 付近および 1010 980 $\mathrm{cm}^{-1}$ に強い吸収が諰められる。グ ループ II のときと同様な理内によりこれらの吸収は CO 伸縮振 動とメチレン樌以れ振動とが結合したものと帰属する。

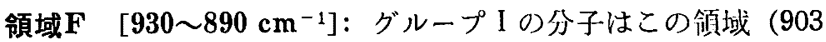
$\pm 23 \mathrm{~cm}^{-1}$ ) に 1 個ないし 2 個の強度強または中の收収をもち, 他のグループでは弱い吸收しか浲められない。ジメチル・ホルマ ール, メチル・エチルホルマール, ジメチル・アセタールにおい ては 929〜870 $\mathrm{cm}^{-1}$ に強い吸収があり, $\mathrm{CH}_{3} \mathrm{O}$ 基のメチル横ゆ れ振動と帰属されている4)。これらの事実を総合してグループI のこの領域の吸収を $\mathrm{CH}_{3} \mathrm{O}$ 基のメチル横ゆれ振動と帰属与る。

領域G $\left[890 \mathrm{~cm}^{-1}\right.$ 以下]：オルトギ酸メチルおよびオルト酢 酸メチルではこの領域に弱いまたはきわめて弱い吸収が 1 個ずつ あるのみであるが，それ以外の分子では強度中に近い吸収を 2 個 ないし 3 個もっている。したがってこの領域の吸収はすべてメチ レン基によるものであり，しかもメチレン横ゆれ振動以外に考え られない。オルトギ酸メチルおよびオルト酢酸メチルのこの領域 の吸収は低波数の原振動の倍振動であろう。この領域のスペクト ルの詳細な検討は分子の回転異性体の研究にきわめて役に立つこ とであるがとれは今後の問題に残すことにする。

以上述べた結果をまとめて表 2 に記した。ここに得られた経駼 的帰属をむとにして各物質のスペクトルを蕨密に帰属し, 分子構 造を決定した結果については以後の報告に順次発表する予定であ る。

本研究を行なうにあたり適切な助言をいただいた当所益子洋一 郎博士に厚く御礼申し上げる。また試料の精製を援助された鈴木 昭夫技官，スペクトル測定に協力された坂口健践氏に謝意を表す る。

\title{
酸化バナジゥム $(\mathrm{V})$ 触媒による一酸化炭素の酸化機構
}

\author{
(昭和 35 年 2 月 20 日受理)
}

多羅間公雄†寺西士一郎・安井昭 夫博

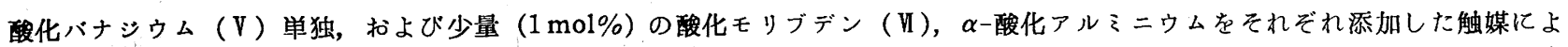
る一酸化炭素酸化の機構, 添加物の作用を速度論的に明らかにする目的で, てれら触媒による酸素吸着, 流通法による一酸化炭素 酸化反応速度の湘定を行なった。酸素の吸着等温線はいずれの触媒でも Langmuir 型の解晟吸着の式が適用さ机, 吸着熱として $\mathrm{V}_{2} \mathrm{O}_{5}, \mathrm{~V}_{2} \mathrm{O}_{5}-\mathrm{MoO}_{3}, \mathrm{~V}_{2} \mathrm{O}_{5}-\alpha-\mathrm{Al}_{2} \mathrm{O}_{3}$ についてそれぞれ 20.3, $15.2,22.7 \mathrm{kcal} / \mathrm{mol}$ の值がえられた。てれらの能媒による一酸化 炭素酸化反応はいずれも吸着一酸化炭素と吸着酸素原子の表面反応を律速過程とする機構で起るとして実跧絬果が满足に説明され またての表面反応の活性化熱として， $\mathrm{V}_{2} \mathrm{O}_{5}, \mathrm{~V}_{2} \mathrm{O}_{5}-\mathrm{MoO}_{3}, \mathrm{~V}_{2} \mathrm{O}_{5}-\alpha-\mathrm{Al}_{2} \mathrm{O}_{3}$ そついてそれぞれ $28.4,22.4,26.1 \mathrm{kcal} / \mathrm{mol}$ の值が えられた。これらの実験結果から加えられた少量の酸化モリブデン（U）は主として表面反応の過程の活性化熱を下げるてとによ り助触媒として作用し，一方 $\alpha$-酸化アルミニウムは $\theta_{\mathrm{O}}, \theta_{\mathrm{Co}}\left(\theta_{\mathrm{O}}, \theta_{\mathrm{co}}\right.$ は $\mathrm{O}, \mathrm{CO}$ の表面被覆率) の增加と, 表面反応過程の活 性化熱をわずかながら低下させるととによって助触媒作用を行なうととが速度諭的に結論された。
\end{abstract}


物理的，化学的諸性質とその触媒作用との関連性をより詳細に検 討するため，一連の研究2)を行なっている。本報では酸化バナジ ウム (V)単独, および少量の不純物 $\left(\mathrm{MoO}_{3}, \alpha-\mathrm{Al}_{2} \mathrm{O}_{3}\right)$ を添加 した触媒による一酸化炭素の酸化機構について研究した結果を報 告する。

金属酸化物による一酸化炭素酸化反応については, 主として半 導体の蟲媒作用を調べるために Wagner ${ }^{3)}$, Parravano4), Sch$\mathrm{wab}^{5}$ ) らが研究し, 半導体特性と触媒活性の間に関连性のある ことが認められている。また少量の不純物を加え原子洒制御した 触媒を用いてその半導体特性と触媒反応の活性化熱の間に平行関 係のあることも指摘されている。しかしかれらの結果は必ずしも 一致しておらず，とくに不純物を少量加えた場合の半導体特性と 触媒活性の関係についてはまったく相反する結果がえられてい る6う。これは,これらの諸研究において速度諭的な裏づけがないこ とによるものと思われる。

酸化バナジウム $(\mathrm{V})$ 蚛媒による一酸化炭素の酸化機構につい てはわれわれが研究遂行中 Hughes7) の研究結果が報告された が，これに用いられた触媒は詳細がわからずその表面積の大きい ことから推して酸化バナジウム（V）単独触媒ではないようであ る。われわれは酸化バナジウム（V）単独，および少量の不純物 として酸化モリブデン（VI）または $\alpha$-酸化アルミニウムを加え た触媒について酸素吸着, ならびに一酸化炭素の酸化反応を行な い, その反応機構について調べ，とくに添加不純物の素反応過程 に与える影響を速度論的に検討した。

\section{2 試料および実験法}

\section{1 試 料}

実賖に用いた陵化バナジウム（V）単独触媒は，精製したバナ

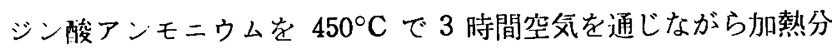
解してつくった酸化バナジウム（V） $\left(\mathrm{V}_{2} \mathrm{O}_{5}(\mathrm{~A})\right.$ とする）をさ らに $800^{\circ} \mathrm{C}$ で 1 時閒加熱溶融後取り出し, 粉硴したものである $\left(\mathrm{V}_{2} \mathrm{O}_{5}(\mathrm{~B})\right.$ とする)。酸化バナジウム $(\mathrm{V})$ に酸化モリブデン(V) （または $\alpha$-酸化アルミニウム）を添加した触媒はいずれも上記 $\mathrm{V}_{2} \mathrm{O}_{5}(\mathrm{~A})$ K $1 \mathrm{~mol} \%$ 計算量の酸化モリブデン（U）（または $\alpha$ 酸化アルミニウム) を加え，単独触媒の場合と同一条件で融解し， 冷却後粉厒したものである。これらの触媒の表面積は（炭酸ガス を用いて BET 法によりー78 ${ }^{\circ} \mathrm{C}$ で測定した) $\mathrm{V}_{2} \mathrm{O}_{5}(\mathrm{~A}), \mathrm{V}_{2} \mathrm{O}_{5}(\mathrm{~B})$ ， $\mathrm{V}_{2} \mathrm{O}_{5}-\mathrm{MoO}_{3}, \mathrm{~V}_{2} \mathrm{O}_{5}-\alpha-\mathrm{Al}_{2} \mathrm{O}_{3}$ のそれぞれについて 2.57, 2.12, $1.87, \quad 0.89 \mathrm{~m}^{2} / \mathrm{g}$ であった。なお上記の酸化モリブデン（V） は精製したモリブデン酸アンモニウムを $450^{\circ} \mathrm{C}, 3$ 時間空気中で 加熱分解与ることによりつくった。 $\alpha$-酸化アルミニウムは市販の $\alpha$-酸化アルミニウムを硝酸洗浄し精製したものである。

\section{2 実験装畐および実験法}

触媒に対する酸菜の吸着実験には通常の恒容静置法の装置を用 い, それぞれの触媒について酸素の吸着等温線および吸着速度を 測定した。脱着操作は，実験より $50^{\circ} \mathrm{C}$ 高以温度で $1 \times 10^{-4} \mathrm{~mm}$ $\mathrm{Hg}$ 程度の圧力になるまで行なった。

一酸化炭素酸化の実験は流通法で行なった。一酸化炭素, 酸 素, 窒素の一定混合比のガスを五酸化リンで乾燥後流速計をへて 一定量 $(0.2 \mathrm{~g})$ の触媒を充てんした反応管中に導き, 反応により 生成した炭酸ガスをオルザットのガス分析装置で分析し，ガス収 縮を考慮に入れ一酸化炭素の反応率を各温度において算出した。

\section{3 実験結果および考察}

\section{1 触媒に対する酸素の吸着}

$\mathrm{V}_{2} \mathrm{O}_{5}(\mathrm{~B}), \mathrm{V}_{2} \mathrm{O}_{5}-\mathrm{MoO}_{3}$ ( $\left.1 \mathrm{~mol} \%\right), \mathrm{V}_{2} \mathrm{O}_{5}-\alpha-\mathrm{Al}_{2} \mathrm{O}_{3}(1 \mathrm{~mol} \%)$ の冬蟲媒に対する酸素の吸着等温線はそれぞれ表 1 に記した条件 の範囲において求めた。

酸絜の吸着等温線はいずれの触媒でも近似的に Langmuir 型 の解離吸着の式 (1) が適用されることがみとめられた。

$$
1 / \sqrt{p_{e}}=S \sqrt{K} / v_{e}-\sqrt{K}
$$

$K$ : 吸着平衡定数 $(1 / \mathrm{mmHg})$

$v_{e}: p_{e}(\mathrm{mmHg})$ での酸素の平衡吸着量 $(\mathrm{mol} / \mathrm{g})$

$S$ : 有効吸着表面積（最大吸着可能量 $\mathrm{mol} / \mathrm{g}$ )

(1) 式の $1 / \sqrt{p_{e}} \sim 1 / v_{e}$ の作図から $K, S$ が算出され, また $K$ の温度变化から平均の吸着熱 $q(\mathrm{kcal} / \mathrm{mol})$ が求められる。結 果は表 1 に一括して示した。この結果からこれらの触媒では酸素 は解嶊吸着していること，酸化モリブデン（V）を加えると吸着 熱がやや小さくなるが， $\alpha$-酸化アルミニウムではあまり変化しな いことがわかる（変化の方向はやや大きくなる方向である)。上 記蟲媒に対する酸素の吸着速度については温度 $370^{\circ} \sim 450^{\circ} \mathrm{C}$, 酸 素初圧 1 〜 $20 \mathrm{mmHg}$ の条件で測定した。いずれの場合にも吸着 速度と吸着量の間に,

$$
\begin{aligned}
& \frac{\mathrm{d} v}{\mathrm{~d} t}=a \cdot e^{-\alpha \cdot v} \\
& v: \text { 四着量 } \\
& \alpha: \text { 定数 } \\
& a: \text { 初速度 }
\end{aligned}
$$

\begin{tabular}{|c|c|c|}
\hline & $S_{A}\left(\mathrm{~m}^{2} / \mathrm{g}\right)$ & $S(\mathrm{~mol} / \mathrm{g})$ \\
\hline $\mathrm{V}_{2} \mathrm{O}_{5}(\mathrm{~B})$ & 2.12 & $2.03 \times 10^{-5}$ \\
\hline $\mathrm{V}_{2} \mathrm{O}_{5}-\mathrm{MoO}_{3}(1 \mathrm{~mol} \%)$ & 1.87 & $6.70 \times 10^{-6}$ \\
\hline $\mathrm{V}_{2} \mathrm{O}_{5}-\alpha-\mathrm{Al}_{2} \mathrm{O}_{3}(1 \mathrm{~mol} \%)$ & 0.89 & $8.92 \times 10^{-6}$ \\
\hline
\end{tabular}

のいわゆる Zeldovich の式早が適用されることがわかった。実 験值を(2) 式に適用することにより初速度 $a$ を算出し, この $a$ の 温度変化から吸着活性化熱を求めた。これらの結果を表 2 に示し た。表 2 から酸化モリブデン（U），酸化アルミニウムを添加

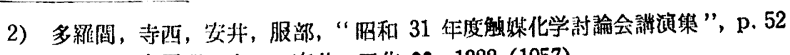
(1956); 多羅間, 寺西, 安井, 工化 60, 1222 (1957).

3) C. Wagner, J. Chem. Phys. 18, 69 (1950).

4) G. Parravano, J. Am. Chem. Soc. 75, 1448 (1953).
の酸素吸着

$K(1 / \mathrm{mmHg}) \quad q(\mathrm{kcal} / \mathrm{mol}) \quad$ 测定条件

$3.54 \times 10^{-9} \mathrm{e}^{20300 / R T}$

20.3

$6.14 \times 10^{-8} \mathrm{e}^{15200 / R T}$

15.2

$1.20 \times 10^{-10} \mathrm{e}^{22700 / R T}$

22.7 $\left\{425^{\circ} \sim 450^{\circ} \mathrm{C}\right.$ $\{100 \sim 200 \mathrm{mmHg}$ $\left\{424^{\circ} \sim 435^{\circ} \mathrm{C}\right.$ $\{0.6 \sim 6 \mathrm{~mm} \mathrm{Hg}$ $\left\{424^{\circ} \sim 435^{\circ} \mathrm{C}\right.$ $1 \sim 10 \mathrm{mmHg}$

5) G. M. Schwab, J. Block, Z. Phys. Chem. (N. F.) 1, 42 (1954).

6)たとえば、牧島、“化学增利 2 号”, p. 61 (1957) 化学同人出版.

7) M. F. Hughes, G. R. Hill, J. Phys. Chem. 50, 388 (1955).

8) Ya. Zeldovich, Acta. Physicochim. (U.R.S.S.) 1, 449 (1934) 


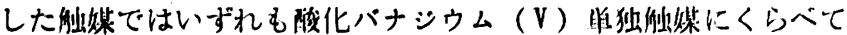

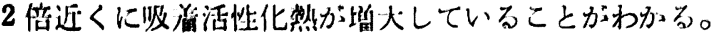

表 2 強媒への帔来の吸着沾度

$$
\begin{gathered}
E(\mathrm{kcal} / \\
\mathrm{mol})
\end{gathered} \text { 洲定条俳: }
$$

$\begin{array}{llcc}\mathrm{V}_{2} \mathrm{O}_{3}(\mathrm{~B}) & 6.90 & 378^{\circ} \sim 434^{\circ} \mathrm{C} & P_{\mathrm{O}_{2}} \leftrightharpoons 17 \mathrm{~mm} \mathrm{Hg} \\ \mathrm{V}_{2} \mathrm{O}_{5}-\mathrm{MoO}_{3}(1 \mathrm{~mol} \%) & 10.5 & \prime \prime \\ \mathrm{V}_{2} \mathrm{O}_{3}-\alpha-\mathrm{Al}_{2} \mathrm{O}_{3}(1 \mathrm{~mol} \%) & 11.9 & \prime \prime\end{array}$

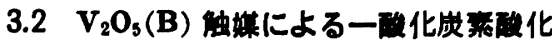

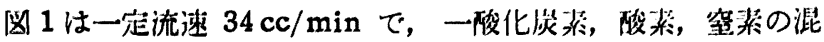
合比を変化させたときの反応汻と温度との関係を一括して示した ものである。この垁駼絬果は一酸化炭菜酸化の機槛をつきの上う に考えることによって定量的に説明与ることができる。

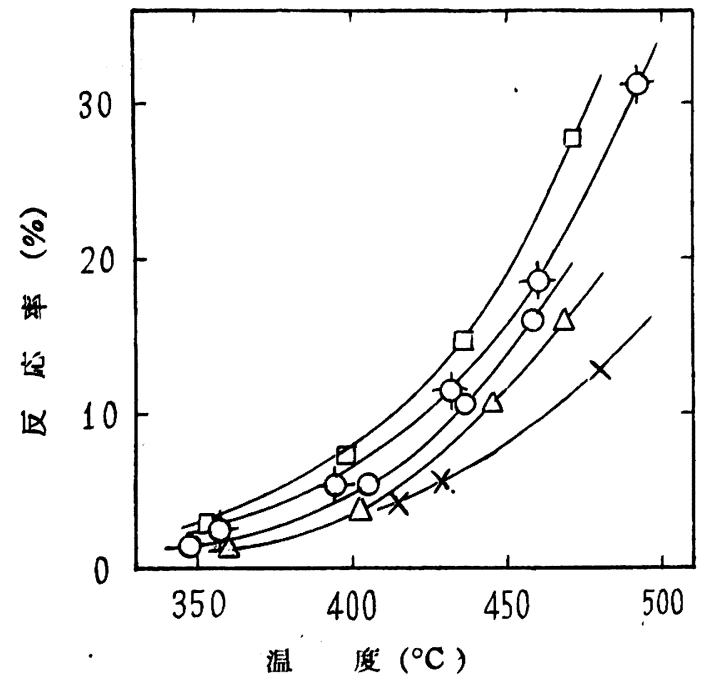

$\mathrm{V}_{2} \mathrm{O}_{3}$ (B) $0.2 \mathrm{~g}$, 流望 $34 \mathrm{cc} / \mathrm{min}$

O: $P_{\mathrm{CO}}=152 \mathrm{mmHg}, P_{\mathrm{O}_{2}}=121 \mathrm{~mm} \mathrm{Hg}$

$\triangle: P_{\mathrm{CO}}=304$ " , $P_{\mathrm{O}_{2}}=121$ "

$\square: P_{\mathrm{co}}=76 \quad$ " , $P_{\mathrm{O}_{2}}=121 "$ "

Q: $P_{\mathrm{CO}}=152 "$ " $P_{\mathrm{O}_{2}}=242$ "

$X: P_{\mathrm{CO}}=152 ", P_{\mathrm{O}_{2}}=60 "$

いずれも䇪蒸を混合して $760 \mathrm{~mm} \mathrm{Hg}$ とする

园 $1 \mathrm{~V}_{2} \mathrm{O}_{5}$ (B) 蚛媒江上万 $\mathrm{CO}$ 酸化

一酸化炭装の反心浫を $x$ (fraction), $W$ を触媒量 $(0.2 \mathrm{~g}), F_{\mathrm{co}}$

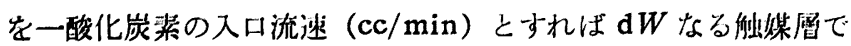
の反応速度 $V$ はガスがピストン流を攵ると仅定してつぎのように 表わされる。

$$
V=\frac{\mathrm{d} x}{\mathrm{~d}\left(W / F_{\mathrm{co}}\right)}\left(\frac{\mathrm{cc}}{\mathrm{g} \cdot \min }\right)
$$

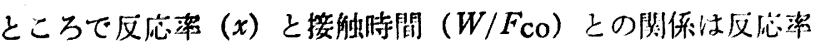

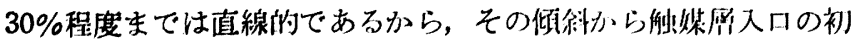
速度Voが求められる。

つぎに触煤表面において一酸化炭菒，陵系はそれぞれ異なった

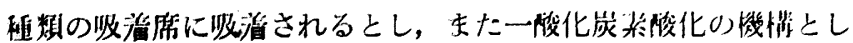

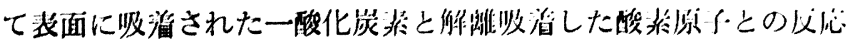
が律速段階であると仮定すれば，

$$
V_{\mathrm{O}}=k \cdot \theta_{\mathrm{Co}} \cdot \theta_{\mathrm{O}}
$$

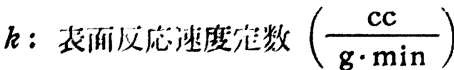

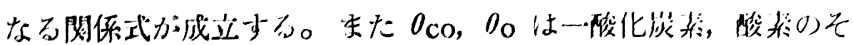
れぞれの表臿被復洋で，

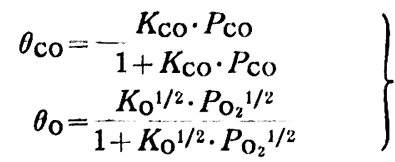

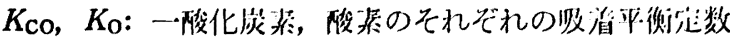
$(1 / \mathrm{mmHg})$

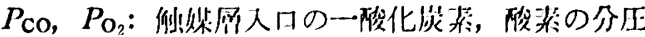
でラシられう。したダーて,

$$
V_{\mathrm{O}}=k \cdot \frac{K_{\mathrm{O}^{1 / 2} \cdot P_{\mathrm{O}_{2}}{ }^{1 / 2}}}{1+K_{\mathrm{O}^{1 / 2}} \cdot P_{\mathrm{O}_{2}}{ }^{1 / 2}} \cdot \frac{K_{\mathrm{CO}} \cdot P_{\mathrm{CO}}}{1+K_{\mathrm{CO}} \cdot P_{\mathrm{CO}}}
$$

（6）式を峳形して，

$$
\left.\begin{array}{rl}
1 / V_{\mathrm{O}} & =\frac{1}{k^{\prime} K_{\mathrm{CO}} \cdot P_{\mathrm{CO}}+\frac{1}{k^{\prime}}} \\
k^{\prime} & =\frac{k K_{\mathrm{O}^{1 / 2}} \cdot P_{\mathrm{O}_{2}}{ }^{1 / 2}}{1+K_{\mathrm{O}^{1 / 2}} \cdot P_{\mathrm{O}_{2}}{ }^{1 / 2}}
\end{array}\right\}
$$

なる咸係式が得られる。少なわち（7）式から $1 / V_{\mathrm{O}}$ と $1 / P_{\mathrm{CO}}$

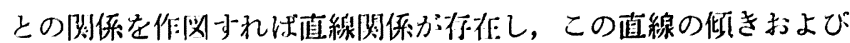

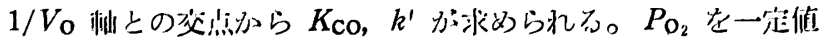
$(121 \mathrm{~mm} \mathrm{Hg})$ にたもち $P_{\text {co }}$ を $76,152,304 \mathrm{~mm} \mathrm{Hg}$ と変化至

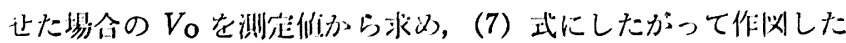
絬果は为 2 に亦した。网 2 から $400^{\circ}, 425^{\circ}, 450^{\circ} \mathrm{C}$ の行温度で ほぼ直線関係の存在していることがわかる。 $k^{\prime} ， K_{\mathrm{Co}}$ の倠につい ては衣 3 に示した。

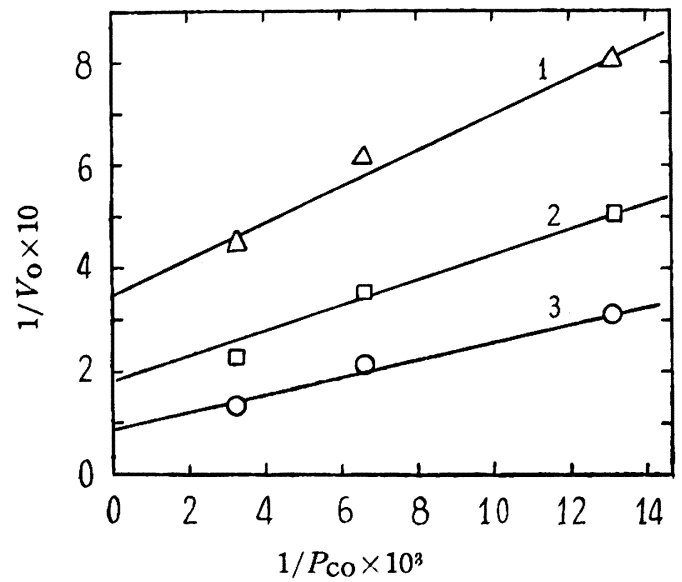

$\mathrm{V}_{2} \mathrm{O}_{5}$ (B) $0.2 \mathrm{~g}$, 流涑 $34 \mathrm{cc} / \mathrm{min}, P_{\mathrm{O}_{2}}=121 \mathrm{~mm} \mathrm{Hg}$ $\triangle: 400^{\circ} \mathrm{C}, \square: 425^{\circ} \mathrm{C}, O: 450^{\circ} \mathrm{C}$

因 $2 \mathrm{~V}_{2} \mathrm{O}_{3}(\mathrm{~B})$ 能媒に上る $\mathrm{CO}$ 酸化 $1 / V_{\mathrm{O}} \sim 1 / P_{\text {co }}$ の plot

表 $3 \mathrm{~V}_{2} \mathrm{O}_{3}(\mathrm{~B})$ 触媒の $k^{\prime}, K_{\mathrm{Co}}, k$ の侹

$\begin{array}{cccc}\text { 温废 }\left({ }^{\circ} \mathrm{C}\right) & k^{\prime} & K_{\mathrm{Co}}(1 / \mathrm{mm} \mathrm{Hg}) & k\left(\frac{\mathrm{cc}}{\mathrm{g} \cdot \mathrm{min}}\right) \\ 400 & 2.87 & 1.09 \times 10^{-2} & 5.09 \\ 425 & 5.73 & 7.42 \times 10^{-3} & 11.5 \\ 450 & 9.73 & 6.13 \times 10^{-2} & 22.4\end{array}$

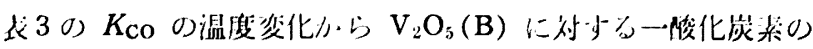
叹焦 $q_{\text {co }}$ として,

$$
q_{\mathrm{co}}=-\boldsymbol{R} T^{2} \frac{\mathrm{d} \ln K_{\mathrm{CO}}}{\mathrm{d} T}-10.9 \mathrm{kcal} / \mathrm{mol}
$$

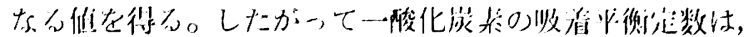

$K_{\mathrm{Co}}-3.10 \times 10^{-6} \mathrm{e}^{106+100 / R T}(1 / \mathrm{m} \mathrm{m} \mathrm{Hg})$

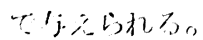

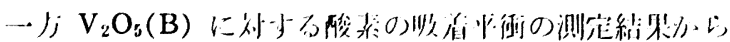

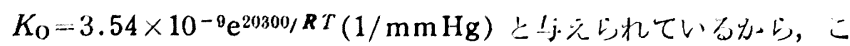




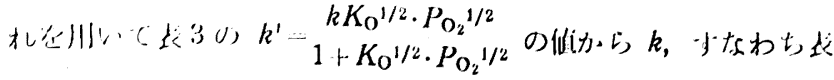

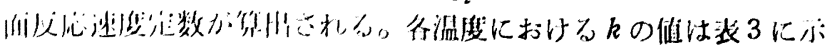

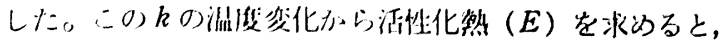

$$
E=\boldsymbol{R} T \cdot \frac{\mathrm{d} \ln k}{\mathrm{~d} T}=28.4 \mathrm{kcal} / \mathrm{mol}
$$

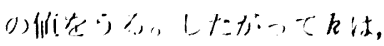

$$
k \quad 8.83 \% 10^{9} \mathrm{e}^{-24400 / R T}\left(\frac{\mathrm{cc}}{\mathrm{g} \cdot \min }\right)
$$

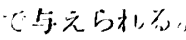

一)兄けけけの活悱:化熟 $E_{\mathrm{A}}$ は,

$$
E_{\Lambda}=\boldsymbol{R} T^{2} \frac{\mathrm{d} \ln V_{\mathrm{O}}}{\mathrm{d} T}
$$

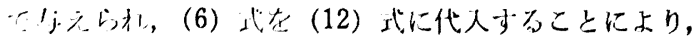

$$
E_{\mathrm{\Lambda}}=E-\left(q_{\mathrm{CO}}+\frac{q_{0}}{2}\right)+\frac{q_{\mathrm{co}}}{1+\frac{1}{K_{\mathrm{CO}} \cdot q_{\mathrm{CO}}}}+\frac{1}{2} \cdot \frac{q_{0}}{1+\frac{1}{\sqrt{ } K_{\mathrm{O}} \cdot P_{\mathrm{O}_{2}}}}
$$

の䋆係式からられ\%。

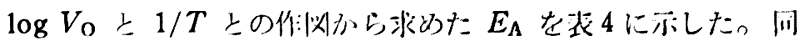
的， '䮖から求められた $q_{\mathrm{o}}, q_{\mathrm{co}}, K_{\mathrm{o}}, K_{\mathrm{co}}$ の们なら $\left(12^{\prime}\right)$

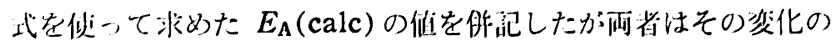

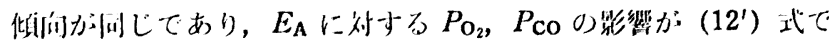
满足されていることをふしてい\%

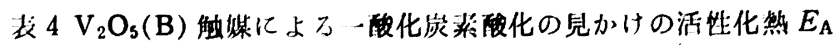

$\begin{array}{cccc}P_{\mathrm{O}_{2}}(\mathrm{~mm} \mathrm{Hg}) & P_{\mathrm{co}}(\mathrm{mm} \mathrm{Hg}) & \begin{array}{c}E_{\mathrm{A} \text { obs }} \\ (\mathrm{kcal} / \mathrm{mol})\end{array} & \begin{array}{c}E_{\mathrm{A} \mathrm{calc}} \\ (\mathrm{kcal} / \mathrm{mol})\end{array} \\ 121 & 76 & 18.5 & 16.2 \\ " 1 & 152 & 20.2 & 18.0 \\ " & 304 & 21.9 & 19.8 \\ 60 & 152 & 19.7 & 17.1 \\ 121 & " & 20.2 & 18.0 \\ 242 & " & (17.9) & 18.2\end{array}$

$3.3 \mathrm{~V}_{2} \mathrm{O}_{5}-\mathrm{MoO}_{3}(1 \mathrm{~mol} \%), \mathrm{V}_{2} \mathrm{O}_{3}-\mathbf{a}-\mathrm{Al}_{2} \mathrm{O}_{3}(1 \mathrm{~mol} \%)$ 触媒に

\section{よる一酸化岸算酸化}

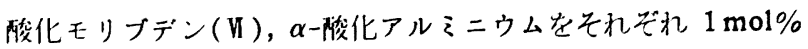

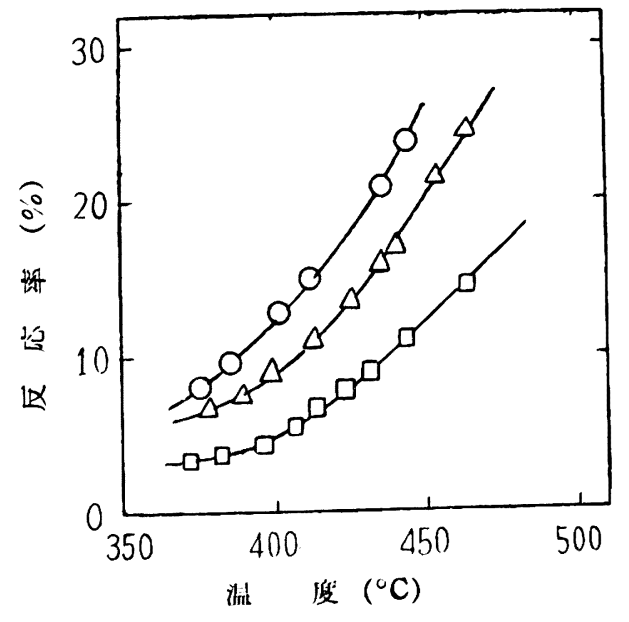

$\mathrm{V}_{2} \mathrm{O}_{5}-\mathrm{MoO}_{3}(1 \mathrm{~mol} \%) 0.2 \mathrm{~g}$, 流速 $57.3 \mathrm{cc} / \mathrm{min}$

○: $P_{\mathrm{CO}}=76 \mathrm{~mm} \mathrm{Hg}, \quad P_{\mathrm{O}_{2}}=121 \mathrm{~mm} \mathrm{Hg}$

A.: $P_{\mathrm{CO}}=152 ", P_{\mathrm{O}_{2}}=121 "$

Г]: $P_{\mathrm{CO}}=304 ", P_{\mathrm{O}_{2}}=121 "$

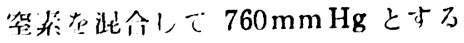

为 $3 \quad \mathrm{~V}_{2} \mathrm{O}_{5}-\mathrm{MoO}_{3}(1 \mathrm{~mol} \%)$ 虽媒による $\mathrm{CO}$ 化

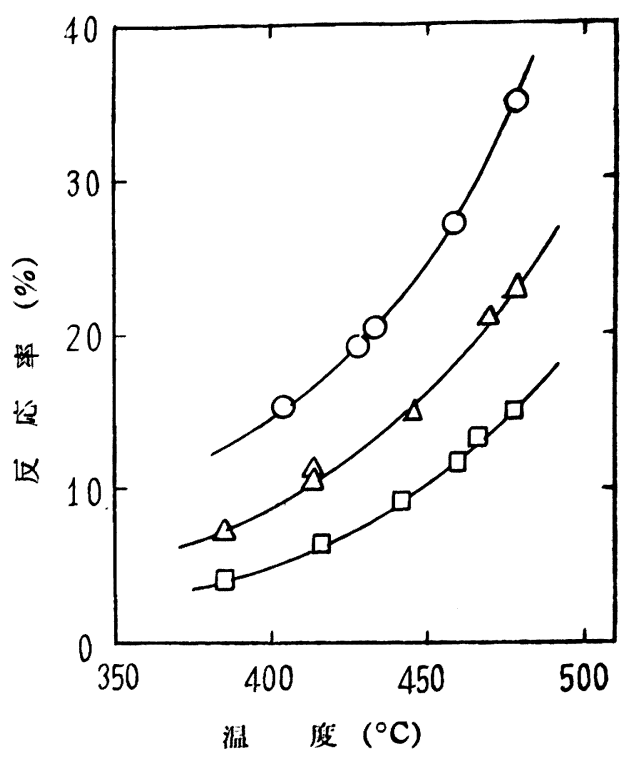

$\mathrm{V}_{2} \mathrm{O}_{3}-\alpha-\mathrm{Al}_{2} \mathrm{O}_{3}(1 \mathrm{~mol} \%) 0.2 \mathrm{~g}$, 流速 $62.7 \mathrm{cc} / \mathrm{min}$

○: $P_{\mathrm{CO}}=76 \mathrm{~mm} \mathrm{Hg}, \quad P_{\mathrm{O}_{2}}=121 \mathrm{~mm} \mathrm{Hg}$

l.: $P_{\mathrm{CO}}=152$ " , $P_{\mathrm{O}_{2}}=121$ "

门]: $P_{\mathrm{CO}}-304$ ", $P_{\mathrm{O}_{2}}=121 "$

窝宾老泥命して $760 \mathrm{mmHg}$ とする

网 $4 \mathrm{~V}_{2} \mathrm{O}_{5}-\alpha-\mathrm{Al}_{2} \mathrm{O}_{3}(1 \mathrm{~mol} \%)$ 触媒に上る $\mathrm{CO}$ 化

添加した蚛媒について一酸化炭慗酸化を行なった結果は四 3,4 に示した。これらはいずれも流速，酸装分压を一定にたもち，一 酸化炭尖分爪:を 76, $152,304 \mathrm{~mm} \mathrm{Hg}$ と変化したときの反応革と

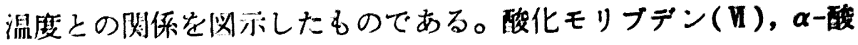
化アルミニウムをそれぞれ添加した触媒はいずれも酸化バナジウ 么（V）単独のものよりも反忍带が大きく，このことからこれら の添加物はいすれれも牥触媒として莇いていることを示している。

泼化バナジウム（V）単独触媒の場合と同㥞に（7）式にしたが つて $1 / V_{0}$ と $1 / P_{\text {co }}$ を作网した絬果は四 5, 6 に示したが，い ずれもほほ直線閔係が存在していてこれら两触媒による一酸化炭

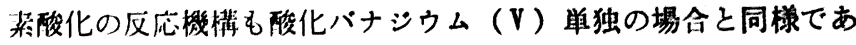
えことを示している。この直線の傾き， $1 / V_{0}$ 軸との交点から求 めた $k^{\prime}, K_{\mathrm{CO}}$ の値は衣 5 (次頁) に示した。表 5 の $K_{\mathrm{Co}}$ の值か b,

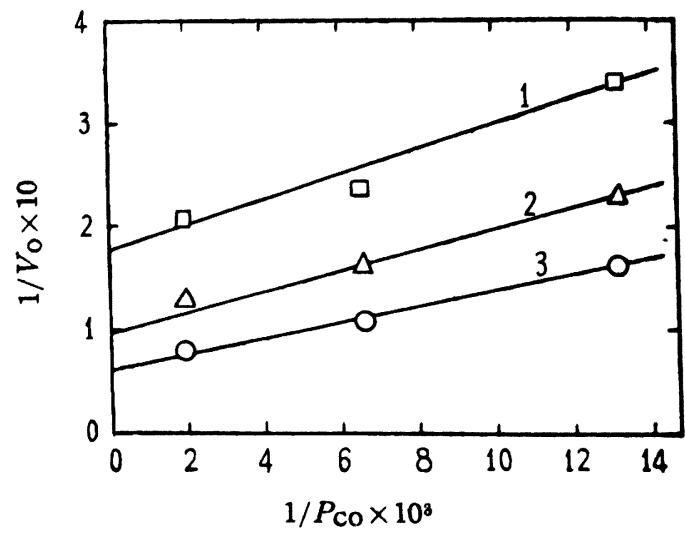

$\mathrm{V}_{2} \mathrm{O}_{3}-\mathrm{MoO}_{3}(1 \mathrm{~mol} \%) 0.2 \mathrm{~g}$, 流迷 $57.3 \mathrm{cc} / \mathrm{min}$, $P_{\mathrm{O}_{2}}=121 \mathrm{~mm} \mathrm{Hg}$,

T: $390^{\circ} \mathrm{C}, \Delta: 415^{\circ} \mathrm{C}, O: 440^{\circ} \mathrm{C}$

图 $5 \quad \mathrm{~V}_{2} \mathrm{O}_{3}-\mathrm{MoO}_{3}(1 \mathrm{~mol} \%)$ 蝶によ万 $\mathrm{CO}$ 化 $1 / V_{0} \sim 1 / P_{\text {co }}$ の plot 


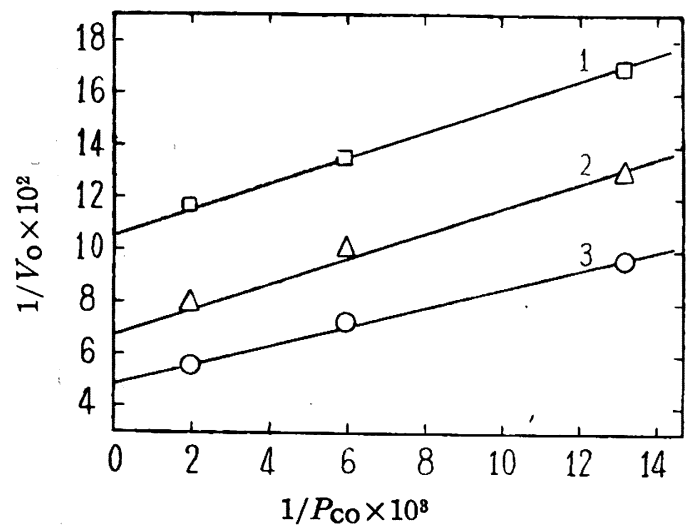

$\mathrm{V}_{2} \mathrm{O}_{5}-\alpha-\mathrm{Al}_{2} \mathrm{O}_{3}(1 \mathrm{~mol} \%) 0.2 \mathrm{~g}$, 流速 $62.7 \mathrm{cc} / \mathrm{min}$, $P_{\mathrm{O}_{2}}=121 \mathrm{~mm} \mathrm{Hg}$,

$\square: 425^{\circ} \mathrm{C}, \triangle: 450^{\circ} \mathrm{C}, \bigcirc: 475^{\circ} \mathrm{C}$

図 $6 \mathrm{~V}_{2} \mathrm{O}_{5}-\alpha-\mathrm{Al}_{2} \mathrm{O}_{3}(1 \mathrm{~mol} \%)$ 触媒による $\mathrm{CO}$ 酸化 $1 / V_{\mathrm{O}} \sim 1 / P_{\text {Co }}$ の plot

表 $5 \mathrm{~V}_{2} \mathrm{O}_{5}-\mathrm{MoO}_{3}(1 \mathrm{~mol} \%), \mathrm{V}_{2} \mathrm{O}_{5}-\alpha-\mathrm{Al}_{2} \mathrm{O}_{3}(1 \mathrm{~mol} \%)$ 触媒に対する $k^{\prime}, K_{\mathrm{CO}}, k$ の值

$\begin{array}{ccccc}\text { 触 媒 } & \begin{array}{c}\text { 温度 } \\ \left({ }^{\circ} \mathrm{C}\right)\end{array} & k^{\prime} & \begin{array}{c}K_{\mathrm{CO}} \\ (1 / \mathrm{mm} \mathrm{Hg})\end{array} & k\left(\frac{\mathrm{cc}}{\mathrm{g} \cdot \mathrm{min}}\right) \\ \mathrm{V}_{2} \mathrm{O}_{5}-\mathrm{MoO}_{3} & 390 & 6.05 & 1.28 \times 10^{-2} & 12.9 \\ & 415 & 10.5 & 1.01 \times 10^{-2} & 25.2 \\ & 440 & 16.9 & 8.00 \times 10^{-3} & 45.6 \\ \mathrm{~V}_{2} \mathrm{O}_{5}-\alpha-\mathrm{Al}_{2} \mathrm{O}_{3} & 425 & 9.82 & 1.98 \times 10^{-2} & 32.5 \\ & 450 & 15.3 & 1.35 \times 10^{-2} & 62.3 \\ & 475 & 23.6 & 9.62 \times 10^{-3} & 118\end{array}$

$\mathrm{V}_{2} \mathrm{O}_{5}-\mathrm{MoO}_{3}(1 \mathrm{~mol} \%)$;

$K_{\mathrm{CO}}=1.87 \times 10^{-5} \mathrm{e}^{8600 / R T}(1 / \mathrm{mmHg})$,

$q_{\mathrm{cO}}=8.60 \mathrm{kcal} / \mathrm{mol}$

$\mathrm{V}_{2} \mathrm{O}_{5}-\alpha-\mathrm{Al}_{2} \mathrm{O}_{3}(1 \mathrm{~mol} \%)$;

$K_{\mathrm{CO}}=3.19 \times 10^{-7} \mathrm{e}^{15300 / R T}(1 / \mathrm{mm} \mathrm{Hg})$,

$q_{\mathrm{co}}=15.3 \mathrm{kcal} / \mathrm{mol}$

の関係式がえられる。

一方 $\mathrm{V}_{2} \mathrm{O}_{5}-\mathrm{MoO}_{3}(1 \mathrm{~mol} \%), \mathrm{V}_{2} \mathrm{O}_{5}-\alpha-\mathrm{Al}_{2} \mathrm{O}_{3}(1 \mathrm{~mol} \%)$ 触媒に 対する酸素の吸着平衝定数 $K_{0}$ はさきの吸着実験加ら表 2 に与え られており, この值と $k^{\prime}$ の值から表面反応速度定数 $k$, 活性化熱 $E$ がつぎのように算出される。

$$
\begin{aligned}
\mathrm{V}_{2} \mathrm{O}_{5} & -\mathrm{MoO}_{3}(1 \mathrm{~mol} \%) ; \\
k & =3.33 \times 10^{8} \mathrm{e}^{-22400 / R T}(\mathrm{cc} / \mathrm{g} \cdot \mathrm{min}), \\
E & =22.4 \mathrm{kcal} / \mathrm{mol} \\
\mathrm{V}_{2} \mathrm{O}_{5}-\alpha-\mathrm{Al}_{2} \mathrm{O}_{3}(1 \mathrm{~mol} \%) ; & \\
k & =4.94 \times 10^{9} \mathrm{e}^{-26100 / R T}(\mathrm{cc} / \mathrm{g} \cdot \mathrm{min}), \\
E & =26.1 \mathrm{kcal} / \mathrm{mol}
\end{aligned}
$$

このようにして求められた $q_{\mathrm{O}}, q_{\mathrm{co}}, K_{\mathrm{O}}, K_{\mathrm{Co}}$ の值を用いて $\left(12^{\prime}\right)$ 式により一酸化炭素酸化の見かけの活性化熱 $E_{\mathrm{A}}$ を計算し

\begin{tabular}{|c|c|c|c|c|}
\hline \multirow{3}{*}{$\begin{array}{r}\mathrm{V}_{2} \mathrm{O}_{5}-\mathrm{MoO}_{3} \\
\quad(1 \mathrm{~mol} \%)\end{array}$} & 121 & 76 & 14.5 & 13.1 \\
\hline & " & 152 & 15.7 & 14.6 \\
\hline & "I & 304 & 16.0 & 15.9 \\
\hline \multirow{3}{*}{$\begin{array}{c}\mathrm{V}_{2} \mathrm{O}_{5}-\alpha-\mathrm{Al}_{2} \mathrm{O}_{3} \\
\quad(1 \mathrm{~mol} \%)\end{array}$} & 121 & 76 & 12.1 & 10.0 \\
\hline & " & 152 & 12.6 & 12.5 \\
\hline & " & 304 & 13.7 & 14.5 \\
\hline
\end{tabular}
た結果は表 6 に示したが，これらは $\log V_{O} \sim 1 / T$ の作図から求 めた $E_{\mathrm{A}}$ に近い值を示している。

表 $6 \mathrm{~V}_{2} \mathrm{O}_{5}-\mathrm{MoO}_{3}(1 \mathrm{~mol} \%), \mathrm{V}_{2} \mathrm{O}_{5}-\alpha-\mathrm{Al}_{2} \mathrm{O}_{3}(1 \mathrm{~mol} \%)$ 触媒による一酸化炭素酸化の見汃けの活性化熱 $E_{\mathrm{A}}$

触 媒 $\quad \begin{gathered}P_{\mathrm{O}_{2}} \\ (\mathrm{mmHg})\end{gathered} \underset{(\mathrm{mm} \mathrm{Hg})}{P_{\mathrm{Co}}} \underset{(\mathrm{kcal} / \mathrm{mol})}{E_{\mathrm{A} \text { obs }}} \underset{(\mathrm{kcal} / \mathrm{mol})}{E_{\mathrm{A}} \text { cals }}$

以上の取り扱いで明らかなように酸化モリブデン( V )， $\alpha$-酸化 アルミニウムを添加した触媒では表面反応の活性化熱 $E か ゙$ 酸化バ ナジウム (V)単独の場合の值に比較してそれぞれ $6.0 \mathrm{kcal} / \mathrm{mol}$, $2.3 \mathrm{kcal} / \mathrm{mol}$ 減少していることがわかる。したがって酸化バナ ジウムに対する少量の酸化モリブデン（VI)， $\alpha$-酸化アルミニウム の作用についてはつぎのように考えることができる。すなわち酸 化モリブデン（VI）の添加は酸素，一酸化炭素の吸着熱が酸化バ ナジウム（V）単独に対するものよりやや小さい方向に作用して いることから $\theta_{\mathrm{O}}, \theta_{\mathrm{CO}}$ の減少をきたすが，表面反応の過程の活 性化熱のかなりの低下がそれを十分におぎなって助触媒として有 効に働いているわけである。一方 $\alpha$-酸化アルミニウムの添加で は一酸化炭素, 酸素の吸着熱が增すことにより $\theta 0, \theta_{\mathrm{Co}}$ の増加 をきたし，また表面反応の過程の少量の活性化熱の低下と相まっ て助触媒作用を営えでいるとみることができよう。

(1955 年 4 月, 日本化学会第 8 年会； 1956 年 4 月，触媒化学討 論会講演）

\section{酸素，一酸化炭素，崖酸ガ八吸着にともなう酸化バナジゥム $(\mathbf{V})$ の電気伝導度の変化}

(昭和 35 年 2 月 20 日受理)

多羅間公雄十・寺西士一郎十・服部研太郎十・安井炤夫胡

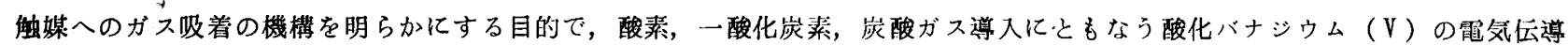
度の変化を追跡した。酸素導入にともなって酸化バナジウム $(\mathrm{V})$ の伝導度 $(\sigma)$ は減少し,その娍少速度は酸素吸祝初期に打いては, $-\mathrm{d} \sigma / \mathrm{d} t=k\left(\sigma-\sigma_{e}\right)$ の関係式で表わされ，また $k$ と酸素圧力 $p$ との間には Langmuir 型の関係が存在するととが見いだされ た。一酸化炭素の導入にともなっては伝導度は增加し，またての変化が非可逆的であるとと，打よび吸着初期の伝導度の増加は， $\mathrm{d} \sigma / \mathrm{d} t=k\left(\sigma_{e}-\sigma\right)$ で表わされることが見いだされた。炭酸ガス尊入にともなっては伝導度は娍少し，またての変化はきわめて小 さく，てれは吸着量のきわめて少ないためであるてとか，吸着实験からも雄かめられた。また炭酸ガス導入にともなら伝導度の变 化の方向は振動容量法による表面電位の測定絬果とも定性的に一致した。 
VII. Structural Viscosity and Spinnability. Part. 3 (pp. 1020 1025)

The spinnability and structural viscosity of acetyl cellulose $(15,20,21,24,25 \%)$-acetone-water mixtures are investigated. The conclusion is the same as the previous one $(\mathrm{VI}), i . e$, the spinnability of the solutions $(20,21,24,25 \%)$ depends mainly on the viscoelastic relaxation phenomena. But the spinnability of $15 \%$ solution is in the mediate region between the viscous flow and the relaxation phenomena, because the relaxation time of $15 \%$ solution is smaller $\left(10^{-2} \sim 10^{-3} \mathrm{sec}\right.$.) than the others $\left(10^{-1} \sim 10^{-2}\right.$ sec. $)$. The results obtained in VI and VII show that the elementary process of spinning in the authors' experiment has the characteristic period of order of $10^{-2}$ sec., though it is much smaller than the actual interval of spinning (spinning length/spinning velocity 1 sec.).

Faculty of Science, Niigata University; Niigata-shi, Niigata, Japan

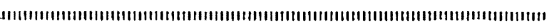

Nippon Kagaku Zasshi, 81, 1025 1028 (1960)

NMR Study on the Solvent Effect of the Fatty AcidAromatic Compound System

by Hiroshi SHIMIZU

The dilution shifts of the proton magnetic resonance of the fatty acid-benzene and fatty acid-pyridine systems were measured. The fatty acids used in this experiment were acetic acid, dichloroacetic acid, propionic acid, $n$-butyric acid, iso-butyric acid, and iso-valeric acid. From the results of the experiment, it was found that; (1) a sort of bond was formed between the $\pi$ electron in the benzene ring and the methyl hydrogen of the fatty acid, (2) the strength of this bond seemed to depend on the chemical activity of the methyl hydrogen, (3) in the system of a basic solvent such as pyridine, the active methyl hydrogen was considered to behave as a weak acid, (4) $\pi \cdots \mathrm{H}-\mathrm{O}$ type bond was found to be formed between the carboxylic hydrogen and the $\pi$ electron system, (5) benzene was found to behave as a polar solvent for the fatty acid, (6) the fatty acids except dichloroacetic acid depolymerized stepwise as polymer $\rightarrow$ dimer $\rightarrow$ monomer when diluted by benzene, however, dichloroacetic acid depolymerized monomer in one step, and (7) the signals of $\beta, \gamma$-hydrogens of the pyridine molecule showed the lower field shifts of the magnitude of $0.6 \sim 0.85$ p. p. m., whereas those of $\alpha$-hydrogen did not show such a large shift. This phenomenon can be attributed to the change of the electronic distribution in the pyridine molecule due to the formation of the $y \mathrm{~N} \cdots \mathrm{H}-\mathrm{O}$ bond.

Faculty of Pharmaceutical Sciences, University of Tokyo; Bunkyo-ku, Tokyo, Japan

Nippon Kagaku Zasshi, 81, 1028 1034 (1960)

Characteristic Frequencies in the Infrared Spectra of Orthoaliphatic Acid Esters

by Kenkichi NUKADA

Infrared spectra of compounds having $\mathrm{C}(\mathrm{OR})_{3}$ skeleton (trimethyl orthoformate, trimethyl orthoacetate, trimethyl ortho- $n$-valerate, triethyl orthoformate, tri- $n$-butyl orthoformate and triethyl orthopropionate) were obtained in $\mathrm{LiF}$ and $\mathrm{NaCl}$ prism regions. From the comparison of these spectra with each others, vibrational modes of functional groups were assigned as follows in liquid state: $2996 \pm 3 \mathrm{~cm} .^{-1}\left(\mathrm{CH}_{3} \mathrm{O}, \mathrm{CH}_{3}\right.$ asym. stretch. $), 2979 \pm 2$ cm. ${ }^{-1}\left(\mathrm{C}_{2} \mathrm{H}_{5} \mathrm{O}, \mathrm{CH}_{3}\right.$ asym. stretch. $), 2960 \mathrm{~cm} .^{-1}\left(\mathrm{CH}_{3}\left(\mathrm{CH}_{2}\right)_{n}\right.$ $\mathrm{C}-\mathrm{O}, n=2,3, \mathrm{CH}_{3}$ asym. stretch. $), 2943 \pm 5 \mathrm{~cm} .^{-1}\left(\mathrm{CH}_{3} \mathrm{O}\right)$, $2933 \pm 1 \mathrm{~cm}^{-1}\left(\mathrm{C}-\mathrm{O}-\mathrm{CH}_{2}, \mathrm{CH}_{2}\right.$ asym. stretch.), $2881 \pm 8 \mathrm{~cm} .^{-1}$ $\left(\mathrm{C}_{2} \mathrm{H}_{5} \mathrm{O}\right.$ and $\mathrm{CH}_{3}\left(\mathrm{CH}_{2}\right)_{n} \mathrm{C}-\mathrm{O}, n=1,2,3, \mathrm{CH}_{3}$ sym. stretch. $)$, $2838 \pm 1 \mathrm{~cm}^{-1}\left(\mathrm{CH}_{3} \mathrm{O}\right), 1455 \pm 22 \mathrm{~cm} .^{-1}\left(\mathrm{CH}_{3}\right.$ asym. deform.), $1369 \pm 16 \mathrm{~cm} .^{-1}\left(\mathrm{CH}_{3}\right.$ sym. deform. $\mathrm{CH}_{2}$ scissoring and wag., and $\mathrm{CH}$ deform. $), 1342 \sim 1258 \mathrm{~cm} .^{-1}\left(\mathrm{CH}_{2}\right.$ wag. and twist.), $1230 \pm 9, \quad 1170 \sim 1100$ and $1070 \sim 1035 \mathrm{~cm} .^{-1}\left(-\mathrm{C}\left(\mathrm{OCH}_{3}\right)_{3}\right.$ skeletal), $1100 \sim 1010 \mathrm{~cm}^{-1}\left(\mathrm{HC}\left(\mathrm{OCH}_{2}\right)_{3}\right.$ skeletal $), 1050$ and $1010 \sim 980 \mathrm{~cm} .^{-1}\left(-\mathrm{CH}_{2} \mathrm{C}\left(\mathrm{OCH}_{2}\right)_{3}\right.$ skeletal $), 903 \pm 23 \mathrm{~cm} .^{-1}$ $\left(\mathrm{CH}_{3} \mathrm{O}, \mathrm{CH}_{3}\right.$ rocking) and below $890 \mathrm{~cm} .^{-1}\left(\mathrm{CH}_{2}\right.$ rocking). This assignment is consistent with that of formals and acetals discussed in the preceding paper.

The Government Chemical Industrial Research Institute of Tokyo; Shibuya-ku, Tokyo, Japan

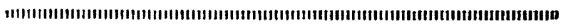

Nippon Kagaku Zasshi, 81, 1034 1038 (1960)

Oxidation Mechanism of Carbon Monoxide on $\mathrm{V}_{2} \mathrm{O}_{5}$ Catalysts

by Kimio TARAMA, Shiichiro TERANISHI and Teruo YASUI

A kinetic investigation was conducted on the $\mathrm{V}_{2} \mathrm{O}_{5}$ catalysed oxidation of carbon monoxide and on the promotor action of $\mathrm{MoO}_{3}$ and $\alpha-\mathrm{Al}_{2} \mathrm{O}_{3}$ on the catalyst. The adsorption isotherms of oxygen on the catalyst satisfied the Langmuir's equation of dissociative adsorption, and values of $20.3,15.3$ and $22.7 \mathrm{kcal} . / \mathrm{mol}$. were obtained for the heat of adsorption for oxygen on $\mathrm{V}_{2} \mathrm{O}_{5}$, $\mathrm{V}_{2} \mathrm{O}_{5}-\mathrm{MoO}_{3} \quad(1 \mathrm{~mol} \%)$, and $\mathrm{V}_{2} \mathrm{O}_{5}-\alpha-\mathrm{Al}_{2} \mathrm{O}_{3}$ ( $\left.1 \mathrm{~mol} . \%\right)$ respectively. The rate-determining step in the oxidation was found to be the surface reaction between the adsorbed carbon monoxide and the adsorbed oxygen. Values of $28.4,22.4$ and $26.1 \mathrm{kcal} / \mathrm{mol}$. were obtained for the activation energy of this process on $\mathrm{V}_{2} \mathrm{O}_{5}, \mathrm{~V}_{2} \mathrm{O}_{5}$ $\mathrm{MoO}_{3}$ and $\mathrm{V}_{2} \mathrm{O}_{5}-\alpha-\mathrm{Al}_{2} \mathrm{O}_{3}$ respectively. The results, being kinetically analyzed, showed that the promotor action of $\mathrm{MoO}_{3}$ on $\mathrm{V}_{2} \mathrm{O}_{5}$ consisted in the decrease in the activation energy of surface reaction, and that addition of $\alpha$ $\mathrm{Al}_{2} \mathrm{O}_{3}$ on $\mathrm{V}_{2} \mathrm{O}_{5}$ increased $\theta_{\mathrm{CO}}, \theta_{\mathrm{O}}\left(\theta_{\mathrm{CO}}, \theta_{\mathrm{O}}\right.$ are defined as fraction of surface covered by adsorbed carbon monoxide and oxygen respectively) and made the activation energy of the surface reaction slightly lower.

Department of Fuel Chemistry, Faculty of Engineering, Kyoto University; Sakyo-ku, Kyoto, Japan

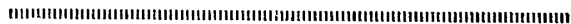

Nippon Kagaku Zasshi, 81, 1038〜1041 (1960)

Changes of Electric Conductivity of $\mathrm{V}_{2} \mathrm{O}_{5}$ Accompanied with Adsorption of Oxygen, Carbon Monoxide and Carbon Dioxide

by Kimio TARAMA, Shiichiro TERANISHI, Kentaro HATTORI and Teruo YASUI

The changes of electric conductivity of $\mathrm{V}_{2} \mathrm{O}_{5}$ accompanied with the adsorption of oxygen, carbon monoxide and carbon dioxide were measured to elucidate the adsorption processes of these gases. The conductivity of $\mathrm{V}_{2} \mathrm{O}_{5}$ decreased as the adsorption of oxygen proceeded, and it was found that the rate of this initial process satisfied the equation $-\mathrm{d} \sigma / \mathrm{d} t=\left(k \sigma-\sigma_{\mathrm{e}}\right)$ and that the linear relation existed between $1 / k$ and $1 / p$ ( $p$; oxygen pressure). On the other hand, the conductivity increased 